\title{
UPAYA MENINGKATKAN KEMAMPUAN MENGENAL ANGKA MELALUI MEDIA KARTU ANGKA PADA ANAK KELOMPOK B TAMAN KANAK-KANAK (TK) ISLAM FATMAWATI KECAMATAN TELANAI PURA KOTA JAMBI
}

Megawati

TK Islam Fatmawati Kota Jambi

Email: megawatitk64@gmail.com

\begin{abstract}
ABSTRAK
Penelitian Tindakan Kelas (PTK) yang penulis lakukan berkaitan dengan masalah yang dihadapi baik oleh guru maupun anak, yaitu bagaimana meningkatkan kemampuan anak mengenal angka melalui media kartu angka. Tujuan yang hendak dicapai dalam penelitian ini adalah ingin mengetahui kemampuan anak dalam mengenal angka melalui media kartu angka, agar lebih menarik dan menyenangkan. Sumber data penelitian ini adalah anak TK Islam Fatmawati sejumlah 21 orang anak. Waktu penelitian pada semester II Tahun Pelajaran 2018/2019. Penelitian dilakukan selama 3 bulan dari bulan Januari s/d Maret 2019. Data yang dikumpulkan adalah data kuantitatif dan data kualitatif. Data kuantitatif adalah data yang diperoleh dari hasil tes formatif pada setiap siklus. Sedangkan data kualitatif berupa hasil observasi pada tiap siklus pembelajaran.

Data yang diperoleh kemudian dianalisa guna untuk mengetahui tingkat penguasaan anak terhadap lambang bilangan 1-10. Hasil penelitian menunjukkan bahwa kemampuan anak mengenal angka melalui media kartu angka pada anak kelompok B dengan metode selain media kartu angka pada studi awal: anak yang belum mampu mengenal angka sebanyak 16 orang $(76,19 \%)$, anak yang mulai mengenal angka 3 orang $(14,29 \%)$ dan anak yang telah mengenal angka 2 orang $(9,52 \%)$.

Setelah menggunakan media kartu angka pada siklus I dan II, diketahui bahwa:1) anak yang tidak mampu mengenal angka 0 orang $(0 \%), 2)$ anak yang mulai mampu mengenal angka berjumlah 3 orang $(14,29 \%), 3)$ anak yang sudah mampu mengenal angka berjumlah 18 orang $(85,71 \%)$.
\end{abstract}

Kata kunci : Anak usia Dini, Media Pembelajaran, media kartu angka.

\section{PENDAHULUAN}

\section{Latar Belakang}

Pada dasarnya anak usia dini adalah sosok individu yang sedang menjalani suatu proses perkembangan dengan pesat dan fundamental bagi kehidupan selanjutnya. Anak usia dini berada pada rentang usia 0-8 tahun. Pada masa ini 
proses pertumbuhan dan perkembangan dalam berbagai bidang sedang mengalami percepatan dalam perkembangan hidup manusia. Proses pembelajaran sebagai bentuk perlakuan yang diberikan kepada anak harus memperhatikan karakteristik yang dimiliki setiap tahapan perkembangan anak tersebut.

Oleh karena itu pendidikan anak usia dini pada dasarnya meliputi seluruh upaya dan tindakan yang dilakukan oleh pendidik dan orang tua dalam proses perawatan, pengasuhan dan pendidikan pada anak dengan menciptakan aura dan lingkungan diman anak dapat mengeksplorasi pengalaman yang meberikan kesempatan padanya untuk mengetahui dan memahami pengalaman belajar yang diprolehnya dari lingkungan, melalui cara mengamati, meniru dan bereksperimen yang berlangsung secara berulang-ulang dan melibatkan seluruh potensi dan kecerdasan anak.

Diantara kompetensi yang harus dimiliki oleh peserta didik Taman KanakKanak adalah mampu mengikuti pendidikan selanjutnya dengan kesiapan yang optimal sesuai dengan tuntutan yang berkembang dalam masyarakat. Kemampuan dasar yang dikembangkan di TK meliputi kemampuan bahasa, fisik/motorik, seni dan kemampuan kognitif. Pengembangan kemampuan kognitif bertujuan meningkatkan kemampuan berpikir anak. Pada kemampuan kognitif tersebut, anak diharapkan dapat mengenal konsep sains dan matematika sederhana.

Pada kegiatan pembelajaran matematika untuk anak harus diorganisir secara terpadu melalui tema-tema pembelajaran yang paling dekat dengan konteks kehidupan anak dan pengalaman-pengalaman riil. Dalam hal ini guru dapat menggunakan media permainan dalam pembelajaran yang memungkinkan anak bekerja dan belajar secara individual, kelompok dan juga klasikal. Penggunaan media pada kegiatan pembelajaran matematika anak usia dini, khususnya dalam pengenalan konsep bilangan bertujuan mengembangkan pemahaman anak terhadap bilangan dan operasi bilangan dengan benda-benda kongkrit sebagai pondasi yang kokoh pada anak untuk mengembangkan kemampuan matematika pada tahap selanjutnya.

Setelah melakukan observasi di lapangan penulis menemukan adanya permasalahan dalam kegiatan pengembangan kemampuan mengenal angka di 
kelas, yaitu rendahnya kemampuan mengenal konsep bilangan di TK Islam Fatmawati pada Kelompok B. Pada saat proses pembelajaran peneliti melihat peran guru masih menekankan pengajaran yang berpusat pada guru (teacher centered). Hal ini dapat dibuktikan dengan adanya peran guru yang terlalu menguasai kelas. Guru dengan spontan memberikan tugas kepada anak tanpa memberikan pilihan kegiatan kepada anak.

Permasalahan lain yang terjadi di TK Islam Fatmawati adalah metode yang digunakan oleh guru masih menggunakan metode drill dan praktek-praktek paperpencil test. Pada pengembangan kognitif khususnya pada pengenalan konsep bilangan, guru memberikan perintah kepada anak agar mengambil majalah dan pensil masing-masing. Selanjutnya guru memberikan contoh kepada anak untuk menghitung jumlah benda yang terdapat pada majalah dan mengisinya dengan angka yang sesuai dengan jumlah benda tersebut pada kolom yang telah disediakan. Setelah anak mengerti, guru menyuruh anak untuk mengerjakannya sendiri. Hal ini merupakan salah satu penyebab rendahnya kemampuan anak dalam mengenal konsep bilangan. . Sebagai indikator rendahnya kemampuan anak di TK tersebut, dapat dilihat bahwa dari 21 anak kelompok B, yang sudah mengenal angka hanya 2 Orang (9,52\%), dan sisanya sebanyak 19 orang $(90,48 \%)$ terdiri dari anak yang belum mengenal angka dan anak yang baru mulai mengenal angka.

Berdasarkan latar belakang di atas penulis tertarik untuk meneliti secara langsung pemanfaatan media kartu angka sebagai salah satu cara meningkatkan kemampuan mengenal konsep bilangan anak TK dan dapat memperbaiki kondisi pembelajaran yang terjadi di TK Islam Fatmawati. Penggunaan media pembelajaran selain dapat memberi rangsangan bagi siswa untuk terjadinya proses belajar, media pembelajaran juga memiliki peranan penting dalam menunjang kualitas proses belajar mengajar. Media pembelajaran merupakan segala sesuatu yang digunakan untuk menyalurkan pesan serta dapat merangsang pikiran, perasaan, perhatian, dan kemauan si belajar sehingga dapat mendorong terjadinya proses belajar yang disengaja, bertujuan, dan terkendali. Selanjut untuk meneliti masalah di atas, Penulis menggunakan metode 
penelitian tindakan kelas dengan judul “Upaya Meningkatkan Kemampuan Mengenal Angka Melalui Media Kartu Angka Pada anak Kelompok B TK Islam Fatmawati".

\section{Rumusan Masalah}

Berdasarkan latar belakang masalah di atas, dapat dirumuskan masalahnya sebagai berikut: "Apakah melalui penggunaan media kartu angka dapat meningkatkan kemampuan mengenal angka pada Anak TK Islam Fatmawati Kec. Telanaipura Kota Jambi?"

\section{Tujuan Penelitian}

Adapun tujuan dari penelitian ini yaitu:

a. Mengembangkan potensi anak dalam mengenal angka dan merangsang kemampuan mengidentifikasi jumlah dan simbol angka melalui media kartu angka.

b. Untuk mengetahui apakah kemampuan mengenal angka siswa kelompok B dapat meningkatkan Melalui Media Kartu Angka di TK Islam Fatmawati Kecamatan Telanaipura Tahun Pelajaran 2018/2019.

\section{Manfaat Penelitian}

Dari hasil penelitian ini diharapkan dapat memberikan kontribusi yang lebih baik bagi anak ataupun guru, dalam meningkatkan serta memperbaiki proses pembelajaran berhitung, selain itu juga diharapkan bagi peneliti lain dapat mengembangkan penggunaan media atau pendekatan lain guna meningkatkan mutu pembelajaran di sekolah.

\section{B. LANDASAN TEORI}

\section{Kemampuan Mengenal Angka}

Kemampuan adalah perpaduan antara teori dan pengalaman yang diperoleh dalam praktek di lapangan, termasuk peningkatan kemampuan menerapkan teknologi yang tepat dalam rangka peningkatan produktivitas kerja (Tadkirotun, 2012).

Menurut Atmosudirdjo (1998:37), kemampuan adalah sebagai sesuatu hal yang perlu dimiliki oleh setiap individu dalam suatu organisasi. Kemampuan 
tersebut terdiri atas tiga jenis kemampuan (abilities) yaitu kemampuan sosial, kemampuan teknik dan kemampuan manajerial.

Sedangkan angka adalah banyaknya benda, Jumlah, satuan system matematika yang dapat diunitkan dan bersifat abstrak. Wardani IGAK (2008:27) mengungkapkan bilangan merupakan suatu konsep tentang bilangan yang terdapat unsure-unsur penting seperti nama, urutan, bilangan dan jumlah. Anak memiliki kemampuan counting (berhitung) sebelum berusia 3 tahun bahwa anak mampu menyebutkan urutan bilangan, misalnya satu, dua, tiga, empat, dan seterusnya. Untuk bisa berhitung anak-anak memulai berhitung dari 1 sampai 9 setelah itu 10 dan seterusnya yaitu bilangan yang terdiri dari 2 angka, misalnya anak mampu menyebutkan bilangan "sebelas" bukan menyebutkan "sepuluh satu" dan sebagainya.

\section{Media Kartu Angka}

Kata media berasal dari bahasa Latin "Medius" yang berarti tengah, perantara, dan pengantar, dalam bahasa Arab, media diartikan ssebagai perantara atau pengantar pesan dari pengirim pesan kepada penerima pesan. Menurut Djamarah (1995:136), media adalah alat bantu apa saja yang dapatg dijadikan sebagai penyalur pesan guna mencapai suatu tujuan pembelajaran. Menurut Purnawati dan Eldarni (2001:4), media merupakan sesuatu yang dapat digunakan untuk menyalurkan suatu informasi sehingga dapat merangsang fikiran, persaan, perhatian, dan minat anak sehingga terjadi proses belajar.Istilah media dalam bidang pembelajaran disebut juga media pembelajaran, alat bantu atau media tidak hanya dapat memperlancar proses komunikasi akan tetapi dapat merangsang anak untuk merespon dengan baik segala pesan yang disampaikan.

Kartu angka atau alat peraga kartu adalah alat-alat atau perlengkapan yang digunakan oleh seorang guru dalam mengajar yang berupa kartu dengan bertuliskan angka sesuai dengan tema yang diajarkan. Alat peraga kartu adalah alat bantu bagi anak untuk mengingat pelajaran. Alat peraga kartu huruf dapat menimbulkan kesan di hati sehingga anak-anak tidak mudah melupakannya. Sejalan dengan ingatan anak akan alat peraga itu, ia juga diingatkan dengan 
pelajaran yang disampaikan guru. Semakin kecil anak, ia semakin perlu visualisasi/konkret (perlu lebih banyak alat peraga) yang dapat disentuh, dilihat, dirasakan, dan didengarnya (Nurani, 2012).

Langkah-Langkah Penerapan Kartu Angka Dalam Pembelajaran. Menurut Tadkirotun (2012) kartu angka merupakan fasilitas penting dalam pembelajaran di sekolah karena bermanfaat untuk meningkatkan perhatian anak. Dengan alat peraga kartu, anak diajak secara aktif memperhatikan apa yang diajarkan guru. Satu hal yang harus diingat, walaupun fasilitas alat peraga kartu yang dimiliki sekolah sangat minim, tetapi bila penggunaan alat peraga diikuti dengan metode anak aktif, maka efektifitas pengajaran akan semakin baik.

\section{PELAKSANAAN PERBAIKAN}

\section{Setting Penelitian}

Penelitian ini dilaksanakan di TK Islam Fatmawati Kec. Telanaipura Kota Jambi. Penelitian ini dilaksanakn pada bulan Januari sampai Maret 2019.

\section{Subjek Penelitian}

Subjek penelitian adalah Anak Usia Dini Kelompok B TK Islam Fatmawati Kecamatan Telanaipura Semester Genap Tahun Pelajaran 2018/2019, yang berjumlah 21 orang, terdiri dari 15 anak laki-laki dan 6 anak perempuan. Dan objek penelitiannya adalah mengenal angka dengan media kartu angka.

\section{Rencana Tindakan}

Penelitian ini dikelompokkan menjadi 2 siklus yang tiap siklus terdapat beberapa tahap atau langkah. Adapun tahap-tahap atau langkah tersebut yaitu:

a. Tahap perencanaan

b. Tahap pelaksanaan tindakan

c. Tahap pengamtan dan interpretasi

d. Tahap analisis dan refleksi

\section{Cara Pengumpulan Data}

Untuk mendapatkan data yang diperlukan dalam penelitian ini, maka peneliti menggunakan beberapa tehnik yaitu sebagai berikut : 
a. Observasi

b. Dokumentasi

D. HASIL PENELITIAN DAN PEMBAHASAN

1. Deskripsi Per Siklus

1) Siklus I

a. Tahap Perencanaan

Sebelum melaksanakan Penelitian Tindakan Kelas (PTK), ada beberapa hal yang perlu dilakukan oleh peneliti, diantaranya adalah sebagai berikut:

1. Membuat Rencana Kegiatan Harian (RKH)

2. Membuat Skenario

3. Menyiapkan alat peraga berupa: kartu angka, gambar bunga matahari beragam jumlah daun dan lambang bilangan $1-10$.

4. Menyiapkan Papan Flanel

b. Pelaksanaan Tindakan

1. Judul kegiatan : mencocokkan jumlah daun bunga matahari dengan lambang bilangan $1-10$

2. Penataan ruangan diubah sehingga terdapat area kosong dengan karpet/tikar

3. Pengorganisasian anak : anak-anak berdiri dilantai dengan formasi setengah lingkaran, posisi guru duduk di depan murid-murid.

c. Tahap Pengamatan/Observasi

- Kegiatan guru

a. Guru menyanyikan lagu dengan cepat sehingga murid-murid banyak yang tidak mampu mengikuti dengan baik,

b. Guru tidak menyanyikan lagu baris demi baris sehingga murid-murid kesulitan dalammenghafal lagu yang disampaikan,

c. Dalam menyanyikan lagu, guru tidak membagi kelompok bernyanyi pada anak sehingga lagu yang dinyanyikan anak tidak serempak,.

- Aktivitas murid

a. Pada kegiatan pembukaan murid-murid masih banyak yang diam, hal ini dikarenakan guru terlalu cepat melantunkan lagu, dan anak banyak yang 
tidak bisa mengikuti lagu karena guru tidak menyanyikan terlebih dahulu baris demi baris

b. Pada kegiatan inti anak-anak berebutan dalam menggunakan alat dan media yang digunakan karena guru tidak menyiapakal alat bantu sesuai dengan jumlah murid,

c. Pada kegiatan penutup banyak anak tidak bisa melihat dan mendengar dengan baik apa yang disampaikan oleh guru karena duduk di belakang

- Prestasi siswa

Hasil pengamatan yang sudah dilaksanakan oleh peneliti tentang prestasi anak dapat dilihat dari tabel dibawah ini:

Tabel 1. Hasil pengamatan prestasi siswa siklus 1

\begin{tabular}{|c|l|c|c|c|}
\hline \multirow{2}{*}{ No Nama } & \multicolumn{2}{|c|}{ Kemampuan Mengenal Bilangan } \\
\cline { 3 - 5 } & & $*$ & $* *$ & $* * *$ \\
\hline 1 & Dhiwa Ahmad El Rida & & $* *$ & \\
\hline 2 & Fahmi Arrozan & $*$ & & \\
\hline 3 & M. Irfan Al Fahri & & $* *$ & \\
\hline 4 & M. Khairan Maulana Efendi & & $* *$ & \\
\hline 5 & M. Qodri Ramadhan & & $* *$ & \\
\hline 6 & M. Raja Habibi Aria & $*$ & & \\
\hline 7 & Nurul Aini & & $* *$ & \\
\hline 8 & R. Muhammad Fitra AlQodri & $*$ & & \\
\hline 9 & Rahmat Huda & & & $* * *$ \\
\hline 10 & Refa Febi Maulidya & & $* *$ & \\
\hline 11 & Sanu Zanuri & & $* *$ & \\
\hline 12 & Zaskia Zahra & $*$ & & \\
\hline 13 & Aditiya & & $* *$ & \\
\hline 14 & Ahmad Fahri Arifin & $*$ & & \\
\hline 15 & Alfaris Rafiq Gibran & & \\
\hline
\end{tabular}




\begin{tabular}{|c|l|c|c|c|}
\hline \multirow{2}{*}{ No Nama } & \multicolumn{3}{c|}{ Kemampuan Mengenal Bilangan } \\
\cline { 3 - 5 } & & $*$ & $* *$ & $* * *$ \\
\hline 16 & Aulia Zeni & & $* *$ & \\
\hline 17 & Azka AlGhifari & & $* *$ & \\
\hline 18 & Rini Jasmini & & & $* * *$ \\
\hline 19 & Zafira Putri Diyansah & $*$ & & \\
\hline 20 & M. Asyqar Ryukenzio & & $* *$ & \\
\hline 21 & M. Reputura Gunawan & & $* *$ & \\
\hline & Jumlah & 7 & 12 & 2 \\
\hline
\end{tabular}

Keterangan:

a) * : Belum mengenal angka

b) $* *:$ mulai mengenal angka

c) $* * *$ : sudah mengenal

Dari data yang tertera pada tabel di atas dapat dijelaskan bahwa anak-anak yang belum berkembang terdapat 7 orang anak (33\%), anak-anak yang sudah mulai berkembang ada 12 anak (57\%), dan anak yang sudah berkembang atau sudah mengenal angka ada 2 anak (9,5\%). Dari data ini juga dapat ditarik kesimpulan bahwa perkembangan anak dalam mengenal angka pada siklus pertama belum mencapai kriteria keberhasilan, karena dikatakan berhasil apabila mencapai $85 \%$, sehingga perlu dilakukan perbaikan menggunakan siklus kedua.

d. Tahap refleksi

Dari kajian dan pengamatan yang sudah dilakukan oleh peneliti bahwa ada kekurangan dalam kegiatan pembelajaran sehingga perlu dilakukan perbaikan diantaranya yaitu:

Pada kegiatan pengembangan I (pembuka) :

1. Guru sebaiknya menyanyikan lagu dengan santai

2. guru seharusnya menyanyikan lagu baris demi bari agar murid mudah dalam mengikuti dan menghafal lagu

3. sebaiknya guru harus membagikan kelompok anak dalam bernyanyi sehingga mudah dilakukan evaluasi dan lagu yang dinyanyikan bisa terdengar serempak

Pada kegiatan pengembangan II (kegiatan inti) :

1. Guru seharusnya menyiapakan alat dan bahan yang digunakan sesuai dengan jumlah murid yang ada guna menghindari murid saling berebut 
2. Guru sebaiknya mengajak anak untuk mengenal langsung bentuk tanaman bunga matahari.

Pada kegiatan pengembangan III (kegiatan penutup) :

a. Guru seharusnya mengorganisasikan anak yaitu anak harus disuruh berdiri agar yang berada di belakang dapat memahami dan mendengarkan dengan baik sepeti halnya murid yang berada di depan

b. Guru tidak meminta anak menceritakan kembali apa yang sudah dilaksanakan

Dari hasil pengamatan yang sudah dilakukan masih terdapat kekurangan dan kesalahan maka selanjutnya digunakan perbaikan proses pembelajaran dengan menggunakan siklus kedua.

2) Siklus II

a. Tahap Perencanaan

Sebelum melaksanakan Penelitian Tindakan Kelas (PTK), ada beberapa hal yang perlu dilakukan oleh peneliti, diantaranya adalah sebagai berikut:

1. Membuat Rencana Kegiatan Harian (RKH)

2. Membuat Skenario

3. Menyiapkan alat peraga

4. Menyiapkan Papan Flanel

b. Pelaksanaan Tindakan

Kegiatan Pengembangan I (Pembukaan)

1. Berdo'a sebelum belajar

2. Judul kegiatan menyanyi bersama lagu " $1,2,3$, “

3. Penataan ruang diubah sehingga terdapat area kosong untuk membentuk lingkaran

Kegiatan pengembangan II (inti)

1. Judul kegiatan : mencocokkan jumlah daun bunga matahari dengan lambang bilangan $1-10$

2. Penataan ruangan diubah sehingga terdapat area kosong dengan karpet/tikar

3. Pengorganisasian anak : anak-anak berdiri dilantai dengan formasi setengah lingkaran, posisi duduk guru lebih tinggi daripada murid-murid Kegiatan pengembangan III ( penutup) 
1. Judul kegiatan : meniru lambaian bunga matahari tertiup angin 10 kali

2. Posisi kursi dan meja anak diatur seperti biasa

3. Pengorganisasian : anak-anak berdiri di samping meja masing-masing

4. Berdo'a setelah belajar/sebelum pulang

5. Salam

c. Tahap Pengamatan/Observasi

Hasil observasi kegiatan pembelajaran yang sudah dilakukan oleh peneliti antara lain:

1. Kegiatan guru

Dari hasil pengamatan yang dilakukan oleh peneliti bahwa proses pembelajaran sudah maksimal karena :

a) Guru sudah menyanyikan lagu dengan santai sehingga murid-murid sudah banyak yang mampu mengikuti dengan baik,

b) guru sudah menyanyikan lagu baris demi baris sehingga murid bisa mengikuti dan menghafal

c) guru sudah membentuk kelompok bernyanyi pada anak

d) guru sudah menyiapkan alat dan bahan yang akan digunakan

e) guru sudah memperkenalkan bentuk tanaman bunga matahari yang sebenarnya.

f) guru sudah menyuruh murid untuk berdiri dalam meniru gerakan bunga matahari tertiup angin.

g) guru sudah meminta murid untuk menceritakan kembali apa yang sudah dilaksanakan.

2. Aktivitas murid

Dari hasil pengamatan tentang kegiatan murid sudah terjadi peningkatan karena:

a) Pada kegiatan pembukaan murid-murid sudah banyak yang mengikuti dan bernyanyi,

b) Pada kegiatan inti anak-anak tidak saling berebut alat lagi karena masingmasing sudah memiliki media sendiri. 
c) Pada kegiatan penutup anak-anak sudah bisa melakukan permainan kartu angka dan sudah mampu untuk menceritakan apa yang sudah pernah dilakukan

3. Prestasi anak

Hasil pengamatan yang sudah dilaksanakan oleh peneliti tentang prestasi anak dapat dilihat dari tabel dibawah ini:

Hasil Pengamatan Penilaian konsep mengenal angka siklus 2 (Prestasi anak)

\begin{tabular}{|c|l|c|c|c|}
\hline \multirow{2}{*}{ No } & \multirow{2}{*}{ Nama Anak } & \multicolumn{3}{|c|}{ Kemampuan Mengenal Angka } \\
\cline { 3 - 5 } & & $*$ & $* *$ & $* * *$ \\
\hline 1 & Dhiwa Ahmad El Rida & & & $* * *$ \\
\hline 2 & Fahmi Arrozan & & & $* * *$ \\
\hline 3 & M. Irfan Al Fahri & & & $* * *$ \\
\hline
\end{tabular}

\begin{tabular}{|c|l|c|c|c|}
\hline \multirow{2}{*}{ No } & \multicolumn{2}{|c|}{ Nama Anak } & \multicolumn{3}{l|}{ Kemampuan Mengenal Angka } \\
\cline { 4 - 5 } & & $*$ & $* *$ & $* * *$ \\
\hline 4 & M. Khairan Maulana Efendi & & & $* * *$ \\
\hline 5 & M. Qodri Ramadhan & & & $* * *$ \\
\hline 6 & M. Raja Habibi Aria & & & $* * *$ \\
\hline 7 & Nurul Aini & & & $* * *$ \\
\hline 8 & R. Muhammad Fitra AlQodri & & $* *$ & \\
\hline 9 & Rahmat Huda & & & $* * *$ \\
\hline 10 & Refa Febi Maulidya & & & $* * *$ \\
\hline 11 & Sanu Zanuri & & & $* * *$ \\
\hline 12 & Zaskia Zahra & & & $* * *$ \\
\hline 13 & Aditiya & & & $* * *$ \\
\hline 14 & Ahmad Fahri Arifin & & & $* * *$ \\
\hline 15 & Alfaris Rafiq Gibran & & & $* * *$ \\
\hline 16 & Aulia Zeni & & & $* * *$ \\
\hline 17 & Azka AlGhifari & & $* *$ & \\
\hline 18 & Rini Jasmini & & & $* * *$ \\
\hline 19 & Zafira Putri Diyansah & & & $* * *$ \\
\hline 20 & M. Asyqar Ryukenzio & & 19 \\
\hline 21 & M. Reputura Gunawan & & & \\
\hline
\end{tabular}

Keterangan:
a) * : Belum mengenal angka
b) $* * \quad$ : mulai mengenal angka
c) $* * * \quad$ : sudah mengenal angka 
Dari data yang tertera pada tabel di atas dapat dijelaskan bahwa setelah dilakukan perbaikan dengan siklus dua terdapat peningkatan pengetahuan mengenal angka pada anak yaitu: anak yang belum mengenal angka berjumlah 0 orang $(0 \%)$, anak yang mulai mengenal angka berjumlah 2 orang $(9,55)$ dan yang sudah mengenal angka berjumlah 19 orang (90,45\%). tidak mengenal angka, dan yang masih belum berkembang 2 orang $(9,55 \%)$.

Dengan demikian dapat disimpulkan bahwa tidak perlu dilakukan perbaikan lagi dengan siklus berikutnya karena sudah mencapai kriteria keberhasilan yaitu di atas $(85 \%)$.

d. Tahap refleksi

Dari kajian dan pengamatan yang sudah dilakukan oleh peneliti dalam kegiatan pembelajaran siklus 2, terjadi peningkatan pembelajaran pada guru umumnya dan khusus pada siswa mengalami peningkatan dan memberikan hasil yang cukup memuaskan, hal ini dapat dilihat dari siklus I dimana persentase peningkatan kemampuan anak yaitu dari 12 orang (57\%), meningkat pada siklus II menjadi 19 orang $(90,45 \%)$ anak yang sudah mengenal angka dan hanya 2 orang anak $(9,55 \%)$ yang belum mengenal angka 1-10.

Jadi, dapat dijelaskan bahwa menggunakan media kartu angka dalam proses pembelajaran yang dilakukan di TK Islam Fatmawati Kota Jambi dapat meningkatkan kemampuan anak usia dini khususnya dalam meningkatkan kemampuan mengenal angka.

\section{Pembahasan}

Perencanaan pembelajaran menggunakan media kartu angka bergambar dalam meningkatkan kemampuan mengenal angka/bilangan pada anak usia dini di TK Islam Fatmawati seperti : menentukan bahan pelajaran dan merumuskan tujuan, pengelolaan dan pengorganisasian anak, mengembangkan materi media (alat peraga) pembelajaran, merencanakan skenario kegiatan, merencanakan pengelolaan kelas dan menyiapkan alat penilaian dapat membantu mengembangkan dan meningkatkan tingkat kecerdasan anak. 
Perencanaan yang dilakukan oleh guru dapat membantu pelaksanaan pembelajaran dan tindakan kelas, sehingga pembelajaran dapat dilakukan sesuai dengan sistematika perencanaan. Selain itu perencanaan yang dilakukan dapat dikategorikan "baik" karena sesuai dengan teori.

Langkah-langkah pembelajaran dengan menggunakan kartu angka bergambar dalam meningkatkan kemampuan mengenal angka/bilangan pada anak usia dini di TK Islam Fatmawati sangat menunjang kegiatan pembelajaran. Pengelolaan interaksi kelas, pemberian penilaian proses dan hasil belajar anak.

Peningkatan kemampuan mengenal angka dengan mengggunakan media kartu angka pada anak usia dini di TK Islam Fatmawati setelah dilaksanakan pembelajaran yaitu dari 21 orang anak yang ada, 19 anak sudah mengenal angka/bilangan atau $90,45 \%$ dan hanya 2 anak yang mulai berkembang atau mulai mengenal angka/bilangan sebanyak $9,55 \%$.

\section{E. SIMPULAN DAN SARAN}

\section{Kesimpulan}

Berdasarkan hasil penelitian yang telah dilakukan dapat ditarik kesimpulan bahwa:

1. Penggunaaan media kartu angka yang diterapkan di TK Islam Fatmawati dapat meningkatkan kemampuan mengenal angka serta memberikan hasil yang sangat baik bagi perkembangan kemampuan anak, dimana hasilnya mencapai $90,45 \%$.

2. Metode serta prilaku guru dalam menyampaikan materi merupakan kunci efektifnya proses belajar mengajar di TK Islam Fatmawati.

\section{Saran}

Untuk melaksanakan pembelajaran khususnya dalam meningkatkan kemampuan mengenal anak dan konsep bilangan hendaknya:

1. Guru dapat menggunakan media kartu angka yang bergambar unik dan sesuai dengan kesenangan anak

2. Guru dapat menggunakan pencampuran metode seperti metode pendekatan emosional dengan anak agar penyampian materi dapat berjalan dengan baik 
3. Guru dapat meningkatkan latihan dan bimbingan bagi anak yang belum paham dan belum mengenal angka

\section{DAFTAR PUSTAKA}

Asmani, Jamal Ma'ruf. 2011. Penelitian Tindakan Kelas. Jogjakarta : Laksana

Djamarah. 2002. Strategi Belajar Mengajar. Jakarta : Rineka Cipta

Iskandar. 2011. Penelitian Tindakan Kelas. Jakarta : GP Press

Kayvan, Umy.2009. Permainan Kreatif untuk Mencerdaskan Anak. Jakarta : Media Kita.

Nurani, Yuliani. 2012. Konsep Dasar Pendidikan Anak Usia Dini. Jakarta : PT Indeks

Tim PKP PG PAUD.2008. Panduan Pemantapan Kemampuan Profesion.Jakarta : Universitas Terbuka.

Tadkirotun, Mudfiroh. 2012. Pengembangan Kecerdasan Majemuk.Tangeran : Universitas Terbuka

Wardani IGAK, dkk. 2008. Penelitian Tindakan Kelas. Jakarta : Universitas Terbuka

Rika Ariyani, Editor Jurnal Literasiologi. Literasi Kita Indonesia. STAI Syekh Maulana Qori. Merangin Bangko. 